\title{
Effects of influent concentration and different valence cations on solute preferential transport in inter-tidal zone of Yellow River Estuary
}

\author{
Jiameng Guo ${ }^{1}$, Lei $\mathrm{Wang}^{2, *}$, and Dan $\mathrm{Wu}^{3}$ \\ ${ }^{1}$ Ocean University of China, College of Environmental Science and Engineering, 266000 Qingdao, China \\ ${ }^{2}$ North China Municipal Engineering Design \& Research Institute Co., LTD, 266000 Qingdao, France \\ ${ }^{3}$ Beijing Jiangong Architectural Design and Research Institute, 100000 Beijing, China
}

\begin{abstract}
The migration of land-based pollutants in tidal flat sediments has an important impact on the marine ecological environment. The effects of three influent concentrations and two cation valence states on the preferential transport of $\mathrm{NO}_{3}-\mathrm{N}$ in the sediments of the Yellow River Estuary were studied by soil column experiments. Results showed that the preferential flow and solute transport were more obvious with the increase of influent concentration; The solute potential was increased in the process of solute transport, which led to the rapid flow, shortened the total time, and facilitated the solute transport speed in the soil; The cation in the sediment of the Yellow River Estuary has little effect on the transport of nitrate nitrogen, and the initial penetration time of the penetration curve using $\mathrm{Ca}\left(\mathrm{NO}_{3}\right)_{2}$ as tracer was a little later than that using $\mathrm{KNO}_{3}$ as tracer, but it is not obvious.
\end{abstract}

\section{Introduction}

The preferential transport of solute mainly refers to the imbalance process of solute concentration change caused by the large pores in soil ${ }^{[1]}$. Since 1970 s, priority flow and its influence on solute migration have become one of the hot and difficult issues for water, environment and soil research in Europe and America [2]. Lots of benthic burrowing animals are active in the tidal flat area of the Yellow River Estuary, forming macropores dominated by burrowing animals. The hydrodynamic change is large in this area, and the soil salinization is serious ${ }^{[3]}$.

Recently, the content of inorganic nitrogen in soil, groundwater and estuarine areas has been increased due to the discharge of domestic sewage and the excessive use of agricultural nitrogen, which led to serious pollution ${ }^{[4]}$. Among them, the accumulation of nitrate nitrogen is the largest and exists in the form of non-adsorbable solute. A study has found that the vertical transport of agrochemicals in cultivated land and arid soil was affected by bio-pores under saturated conditions, which connecting the soil surface directly with the drainpipes ${ }^{[5]}$. However, the effects of influent concentration and soil cation valence on preferential transport of nitrate in intertidal sediments with bio-pores under the coastal zone are still not well-understood.

Therefore, the aim of this study was to investigate the effects of different influent concentrations and valence cations on the preferential transport of non-adsorbable solute nitrate nitrogen in the macropores of sediments from the Yellow River Estuary, and to provide a scientific basis for the protection of marine ecological environment.

\section{Materials and Methods}

\subsection{Basic physical and chemical properties of soil}

The soil samples were taken from the Diaokou Course Coast at the Yellow River Delta. The natural water content of the silty soil was $26.2 \%$. The grain size analysis showed that the content of sand was $0.28 \%-13.08 \%$, silt was $68.3 \%-86.1 \%$, clay was $12.4 \%-21.2 \%$. The content of organic matter was $0.47 \%$. A lot of soluble salt ions $\left(\mathrm{Ca}^{2+}\right.$, $\mathrm{Mg}^{2+}, \mathrm{Na}^{+}, \mathrm{Cl}^{-}, \mathrm{SO}_{4}^{2-}, \mathrm{HCO}_{3}^{-}$) existed in the sediments.

\subsection{Experimental device}

The experimental apparatus of solute transport mainly included soil column, Mahalanobis flask and sampling apparatus, as shown in Fig. 1. The inner diameter of the soil column was $15 \mathrm{~cm}$, and the length was $55 \mathrm{~cm}$. the sampling port was at the bottom. Mahalanobis flask was a water supply device to maintain constant water head. The self-designed automatic sampling device included power supply, control circuit, solenoid valve and sampling bottle. To meet the analysis requirements, it was set to automatically take solute samples continuously every 3 hours. 


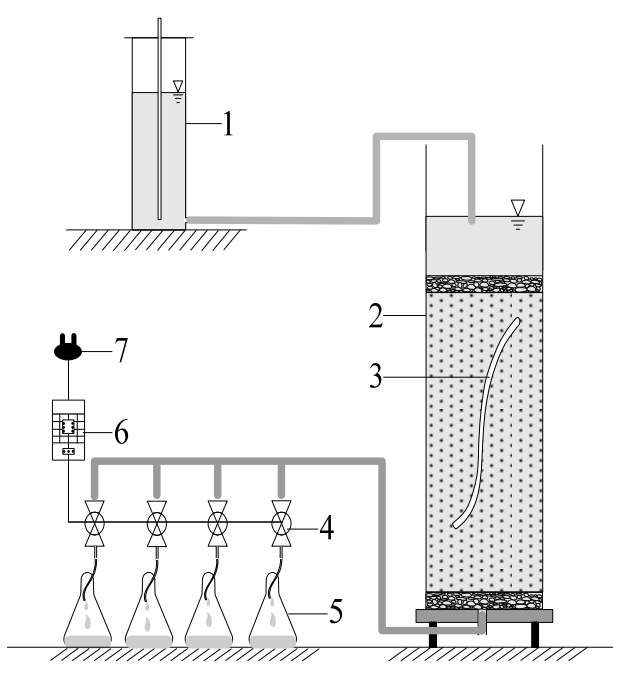

Fig. 1. experimental device (1. martensite flask; 2. soil column; 3. artificial simulation of macropore; 4. solenoid valve; 5 . sampling bottle; 6 . control circuit; 7. power supply)

\subsection{Experimental process}

\subsubsection{Preparation of artificial macroporous soil column}

The soil samples were dried, sieved through $2.0 \mathrm{~mm}$ mesh, and homogenized well. A layer of Vaseline was applied on the inner wall of the PMMA column to prevent edge effect. The order of loading soil samples was as follows: first, 2 $\mathrm{cm}$ thick coarse sand was placed at the bottom of the soil column as the filter layer, and then the soil samples with different water contents were evenly loaded $5 \mathrm{~cm}$ in layers according to the density. Then, a section of $25 \mathrm{~cm}$ long macropore was buried in the soil, and the soil sample was continuously loaded until the height of the soil sample was $35 \mathrm{~cm}$. Finally, $2 \mathrm{~cm}$ thick coarse sand was covered on the surface of the soil sample to prevent the surface of the soil sample from being damaged when solute was added.

\subsubsection{Experimental scheme}

The nitrate nitrogen solution with $\mathrm{NO}_{3}-\mathrm{N}$ concentration $(50 \mathrm{mg} / \mathrm{L}, 100 \mathrm{mg} / \mathrm{L}$ and $200 \mathrm{mg} / \mathrm{L}$ ) was prepared as influent. After the dry soil was loaded, the soil column bottom was desaturated to exhaust the air from the soil sample. When the surface layer of soil sample appears about $0.5 \mathrm{~cm}$, it was considered to saturated, and the latex pipe at the sampling port was clamped in and placed for one day to make the water distribution evenly. During the test, the constant head was maintained at $9 \mathrm{~cm}$ by a Martian flask. $1500 \mathrm{ml}$ of solution (including $\mathrm{NO}_{3}-\mathrm{N}$ ) was applied to the surface of the soil column. The column was leached with distilled water after the infiltration was completed, and the solute concentration was measured every 3 hours, and the volume number was recorded and the flow rate per unit time was calculated. During the test, the soil column is covered with plastic film to avoid evaporation loss.

The effects of different valence states on the preferential migration of nitrate nitrogen were studied by comparing $\mathrm{KNO}_{3}$ and $\mathrm{Ca}\left(\mathrm{NO}_{3}\right)_{2}$. The experimental process was the same as that of the other.

\subsubsection{Determination method}

The determination of nitrate nitrogen was carried out by ultraviolet spectrophotometry, which is derived from the monitoring and analysis method of water and wastewater [6].

\section{Results \& Discussion}

\subsection{Effects of different influent concentration on outflow rate}

Under three influent concentration conditions, the outflow rate hydrograph of soil column samples showed a larger outflow rate at the beginning stage, and the outflow rate gradually decreased with the increase of time, and finally ted to be stable (Fig. 2). When the influent concentration is $200 \mathrm{mg} / \mathrm{L}$, the outflow rate was the fastest. With the decrease of the influent concentration, especially when the influent concentration was $50 \mathrm{mg} / \mathrm{L}$, the outflow rate is significantly lower than the other two higher concentration curves. This is due to the increase of the influent concentration and the solute potential in the process of solute transport, which leads to the fast flow and short total time ${ }^{[7]}$.

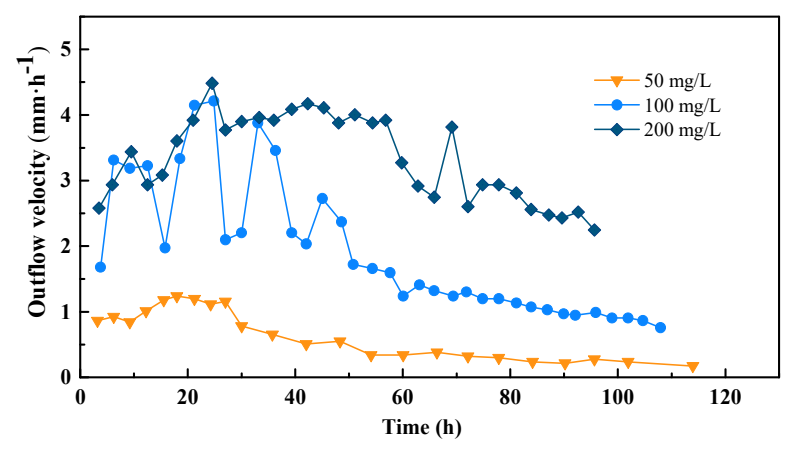

Fig. 2. outflow rate hydrograph of soil column with three influent concentrations

\subsection{Effects of different influent concentrations and valence cations on non-adsorbable solute transport}

Breakthrough curve is an intuitive method to describe preferential flow and solute preferential migration, which can reflect the time characteristics of solute and medium to reach chemical equilibrium ${ }^{[8]}$. The horizontal mark of breakthrough curve is relative pore volume (PV), which is the ratio of outflow volume to soil column pore volume, and the ordinate is the relative concentration $\left(\mathrm{C} / \mathrm{C}_{0}\right)$, which is the ratio of the effluent concentration and the solute concentration. The earlier initial penetration, bimodal phenomenon, tailing and curve asymmetry of the breakthrough curve can clearly indicate the role of macropores. The influence of influent concentration and different valence cations on water infiltration mode can 
also be shown by penetration curve.

\subsubsection{Effects of different influent concentrations on $\mathrm{NO}_{3}-\mathrm{N}$ preferential transport}

Under the three influent concentrations, the breakthrough curves of nitrate nitrogen were different (Fig.3). Under the condition of low influent concentration, the initial breakthrough time was later, with the increase of influent concentration, the initial breakthrough time was earlier, and the relative concentration peak also increased (Fig.3a). According to the breakthrough process line of nitrate nitrogen, the initial breakthrough time of nitrate nitrogen was $24 \mathrm{~h}, 15 \mathrm{~h}$ and $9 \mathrm{~h}$, respectively, which is also advanced with the increase of influent concentration (Fig.3b). Compared with the breakthrough curve with low concentration, the part with high peak value was the role of solute potential in the process of nitrate migration ${ }^{[9]}$. Under the combined action of gravity potential and solute potential, the outflow speed with higher influent concentration was accelerated, the peak value was higher, and the time to complete the outflow is shorter.

Table 1 Relative time variation parameters of nitrate breakthrough curve of three influent concentrations

\begin{tabular}{cccccc}
\hline $\begin{array}{c}\text { Influent } \\
\text { concentrati } \\
\text { on/ mg/L }\end{array}$ & $\begin{array}{c}\text { time of } \\
\text { initial } \\
\text { penetrati } \\
\text { on }\end{array}$ & $\begin{array}{c}\text { Penetrati } \\
\text { on end } \\
\text { relative } \\
\text { time }\end{array}$ & $\begin{array}{c}\text { time of } \\
\text { penetrati } \\
\text { on }\end{array}$ & $\begin{array}{c}\text { Peak value } \\
\text { of relative } \\
\text { concentrati } \\
\text { on }\end{array}$ & $\begin{array}{c}\text { Peak } \\
\text { relati } \\
\text { ve } \\
\text { time }\end{array}$ \\
\hline 50 & 0.68 & 1.03 & 0.35 & 0.403 & 0.85 \\
100 & 0.28 & 2.03 & 1.75 & 0.509 & 1.43 \\
200 & 0.06 & 2.27 & 2.21 & 0.948 & 1.72 \\
\hline
\end{tabular}

Gang et al. (2017) showed that the earlier initial penetration was also one of the characteristics of soil preferential flow ${ }^{[10]}$. Under the same conditions, with the increase of influent concentration, the outflow velocity rate of soil sample water became faster, and the time to complete the outflow was shorter, the phenomenon of solute preferential flow was more obvious (Table 1). When the influent concentration was $200 \mathrm{mg} / \mathrm{L}$, the initial breakthrough time was 0.06 times of pore volume, and the outflow was faster. With the decrease of influent concentration, the initial breakthrough time is delayed, which was 0.28 and 0.68 times of pore volume respectively, and the peak relative concentration also decreased from 0.948 to 0.403 .
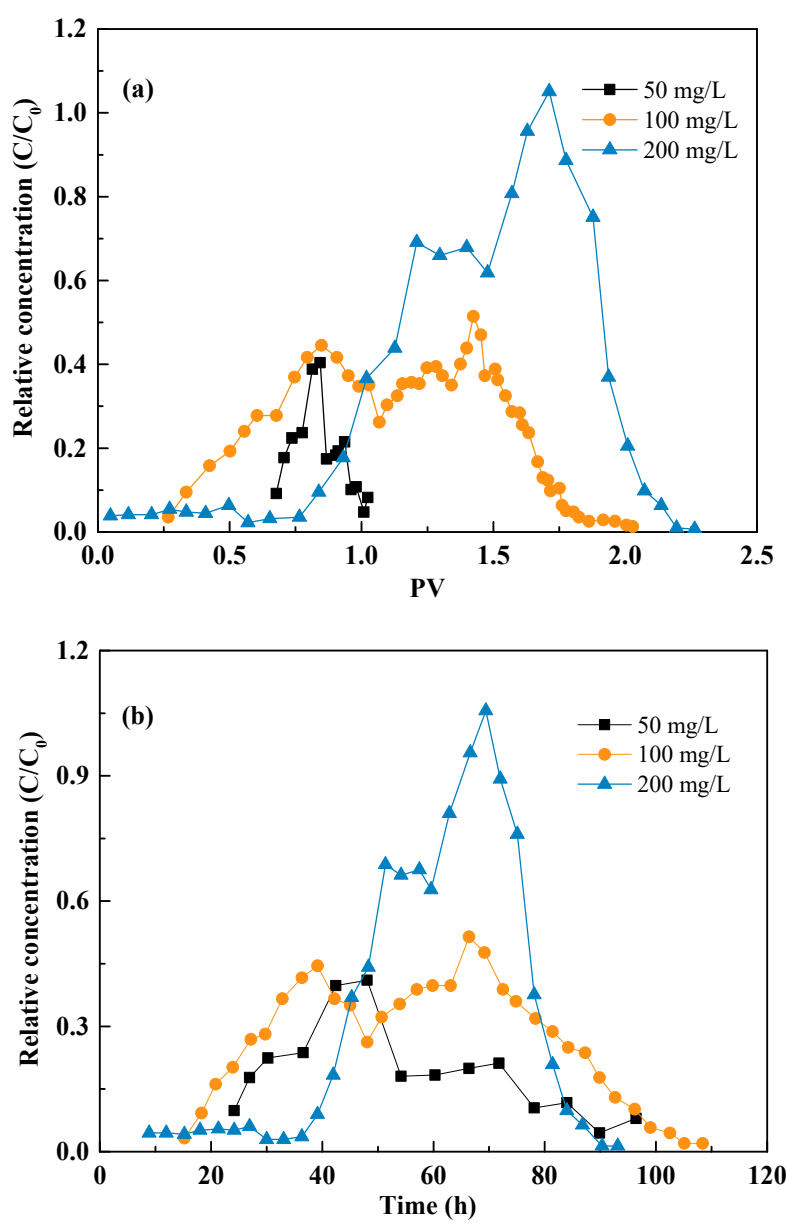

Fig. 3. Nitrate penetration curve and nitrate penetration hydrograph of three influent concentrations

\subsubsection{Effects of different valence cations on $\mathrm{NO}_{3}-\mathrm{N}$ preferential transport}

The breakthrough curve of nitrate nitrogen is also different due to different valence states of cations (Fig. 4). The initial penetration time of $\mathrm{Ca}\left(\mathrm{NO}_{3}\right)_{2}$ tracer penetration curve was a little later than that of $\mathrm{KNO}_{3}$ tracer penetration curve, but it was not obvious, and the tailing characteristics are similar (Fig.4a). According to the breakthrough process line of nitrate nitrogen, the initial breakthrough time of nitrate nitrogen was $33 \mathrm{~h}, 15 \mathrm{~h}$, respectively. The peak value of relative concentration is more obvious. The peak value of penetration curve with $\mathrm{Ca}\left(\mathrm{NO}_{3}\right)_{2}$ as tracer was much higher than that with $\mathrm{KNO}_{3}$ as tracer (Fig.4b). The surface of soil particles was negatively charged, and the presence of high valence ions $\left(\mathrm{Ca}^{2+}\right)$ helped to reduce the rejection of soil colloids to nitrate nitrogen. A study has found that the vertical transport of nitrate nitrogen in soil was slightly affected by different valence cations under saturated conditions, and the main influencing factors were soil water content and soil physical properties ${ }^{[11]}$. 

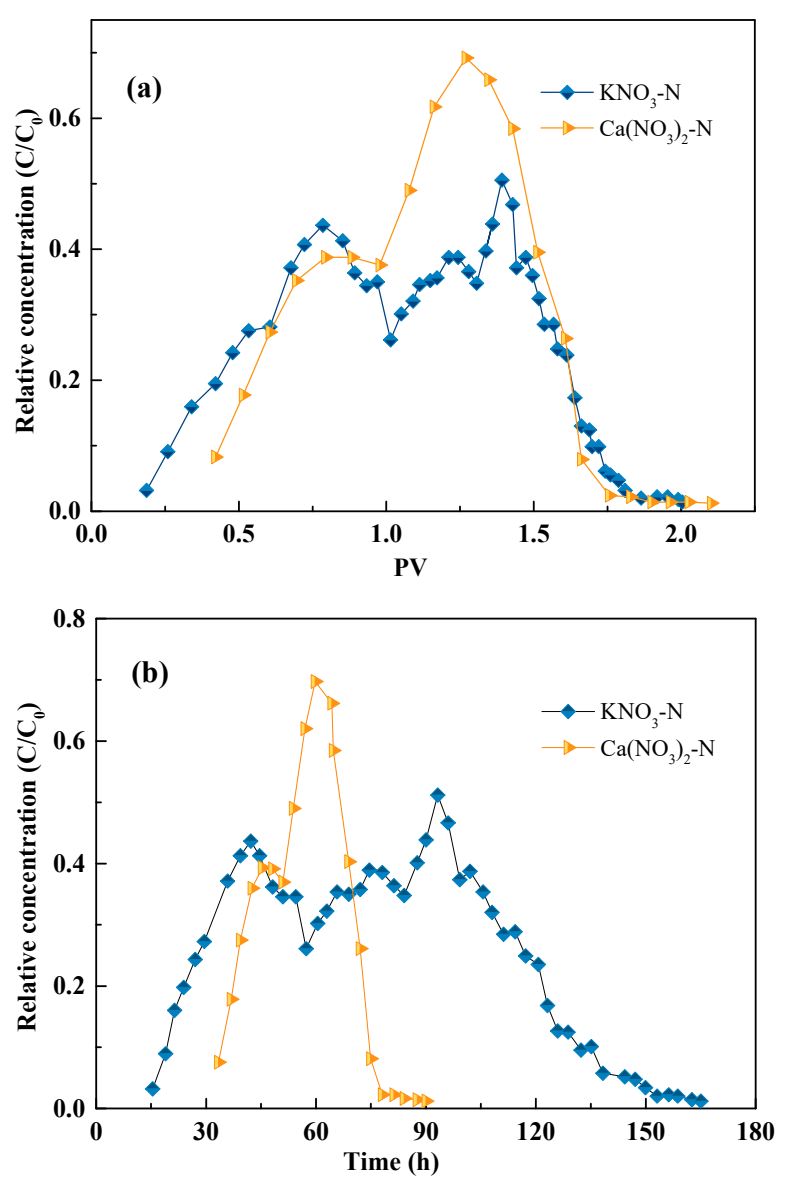

Fig. 4. Nitrate penetration curve and nitrate penetration hydrograph of different valence cations

The peak value of the penetration curve with $\mathrm{Ca}$ $\left(\mathrm{NO}_{3}\right)_{2}$ as tracer was 0.693 , and that of $\mathrm{KNO}_{3}$ as tracer was only 0.509 (Table 2). It is difficult to determine the influence of cation valence on the preferential migration of nitrate nitrogen from peak characteristics. Therefore, it can be concluded that the migration of nitrate nitrogen in the soil sample was little affected by the different valence cations.

Table 2: the breakthrough time curve of different nitrate cations

\begin{tabular}{cccccc}
\hline $\begin{array}{c}\text { Influent } \\
\text { concentrati } \\
\text { on/ } \mathbf{m g} / \mathbf{L}\end{array}$ & $\begin{array}{c}\text { time of } \\
\text { initial } \\
\text { penetrati } \\
\text { on }\end{array}$ & $\begin{array}{c}\text { Penetrati } \\
\text { on end } \\
\text { relative } \\
\text { time }\end{array}$ & $\begin{array}{c}\text { time of } \\
\text { penetrati } \\
\text { on }\end{array}$ & $\begin{array}{c}\text { Peak value } \\
\text { of relative } \\
\text { concentrati } \\
\text { on }\end{array}$ & $\begin{array}{c}\text { Peak } \\
\text { relati } \\
\text { ve } \\
\text { time }\end{array}$ \\
\hline $\mathrm{K}^{+}$ & 0.28 & 2.03 & 1.75 & 0.509 & 1.43 \\
$\mathrm{Ca}^{2+}$ & 0.5 & 2.11 & 1.61 & 0.693 & 1.31 \\
\hline
\end{tabular}

\section{Conclusions}

With the increase of influent concentration, the preferential flow and solute transport were more obvious. In the process of solute transport, the solute potential increases, which led to the rapid outflow and shortened the total time; The solute potential increased, which accelerated the speed of solute transport in the soil and advances the outflow time. The initial penetration time of $\mathrm{Ca}\left(\mathrm{NO}_{3}\right)_{2}$ tracer penetration curve was slightly later than that of $\mathrm{KNO}_{3}$ tracer penetration curve, but it was not obvious, and the tailing characteristics were similar.

\section{References}

1. Kamra, S. K., Lennartz, B., Genuchten, M. Evaluating non-equilibrium solute transport in small soil columns. J. Contam. Hydrol 48, 189-212 (2001)

2. Beven, K., P. F. Germann. Macropores and water flows in soils. Water. Res 18, 1311-1325 (1982)

3. Zc, A., Yz, A., Hl, B., HW B, By, B. Unraveling bacterial community structure and function and their links with natural salinity gradient in the yellow river delta. Sci Total Environ. 23 (2021)

4. He, B., He, J., Wang, L., Zhang, X., Bi, E. Effect of hydrogeological conditions and surface loads on shallow groundwater nitrate pollution in the shaying river basin: based on least squares surface fitting model. Water. Res 163, 114880 (2019)

5. Holbak, M., Abrahamsen, P., Hansen, S., Diamantopoulos, E. A physically based model for preferential water flow and solute transport in drained agricultural fields. Water Resour Res 57 (2021).

6. Causse, J., Thomas, O., Jung, Aude-Valérie, Thomas, M. F. Direct doc and nitrate determination in water using dual pathlength and second derivative uv spectrophotometry. Water. Res 312 (2016)

7. Frey, S. K., Hwang, H. T., Park, Y. J., Hussain, S. I., Lapen, D. R. Dual permeability modeling of tile drain management influences on hydrologic and nutrient transport characteristics in macroporous soil. J Hydrol 535, 392-406 (2016).

8. Zhang, W. J., Yuan, S. S. Characterizing preferential flow in landfilled municipal solid waste. Waste Manag Res 84, 20-28 (2019)

9. F Rezanezhad., C Kleimeier., T Milojevic., H Liu. The role of pore structure on nitrate reduction in peat soil: a physical characterization of pore distribution and solute transport. Wetlands. 231 (2017)

10. Gang, L., Li, J., Li, Y., Wang, T., Liu, Y., Fu, X. Preferential flow characteristics of reclaimed mine soils in a surface coal mine dump. Environ Monit Assess 189, 266 (2017)

11. Wp, A., Qh, B., Zx, B., Gp, A. Experimental investigation and simulation of nitrogen transport in a subsurface infiltration system under saturated and unsaturated conditions. J. Contam. Hydrol 231, 6 (2019) 